\title{
1: $144237996-144322828$
}

National Cancer Institute

\section{Source}

National Cancer Institute. 1:144237996-144322828. NCI Thesaurus. Code C41768.

Physical location of BCL9_Gene 